\title{
PERAN KEUCHIK DALAM PENYELENGGARAAN PEMBANGUNAN DI GAMPONG LAWET KECAMATAN PANTE CEUREUMEN KABUPATEN ACEH BARAT
}

\author{
Aduwina Pakeh \\ aduwina@utu.ac.id
}

\begin{abstract}
The role of keuchik gampong ( village head) in the implementation of development in gampong lawet pante ceureumen sub-district district of aceh the west has been implemented well but need to be increased again. In this research, researchers found that keuchik gampong have undertaken the role well, where keuchik gampong actively down to pitch in communicating, coordinated, move, and provide the motivation to aparat-aparat gampong as well as to the community to participate in the implementation of development. Besides, gampong programs made by keuchik gampong can 's done well, directed, right on target and very help communities gampong lawet The results of the study others are identified of factors affect the role of keuchik gampong in the development that is by factors in support and inhibitors. By factors in support covering, location gampong lawet which is very strategic, potential the diverse and the volition the community to forward, the people of participation is a good enough. While inhibition factors, the low human resources whether it is the community and government officials gampong, and funds apbg to gampong lawet who do not in proportion to the extent needs.
\end{abstract}

Keywords : Keuchik Gampong, development, Gampong Lawet, west Aceh

\begin{abstract}
Abstrak
Peran Keuchik Gampong (Kepala Desa) Dalam Penyelenggaraan Pembangunan di Gampong Lawet Kecamatan Pante Ceureumen Kabupaten Aceh Barat telah dilaksanakan dengan baik namun perlu ditingkatkan lagi. Dalam penelitian ini, peneliti menemukan bahwa Keuchik Gampong sudah melaksanakan perannya dengan baik, dimana Keuchik Gampong secara aktif turun ke lapangan dalam berkomunikasi, berkoordinasi, menggerakkan, dan memberikan motivasi kepada aparat-aparat gampong serta kepada masyarakat untuk ikut serta dalam penyelenggaraan pembangunan. Selain itu, program-program gampong yang dibuat oleh Keuchik Gampong dapat terlaksanakan dengan baik, terarah, tepat sasaran dan sangat membantu masyarakat Gampong Lawet
\end{abstract}


Hasil penelitian lainnya adalah teridentifikasinya faktor yang mempengaruhi Peran Keuchik Gampong Dalam Penyelenggaraan Pembangunan yaitu faktor pendukung dan penghambat. Faktor pendukung meliputi, letak wilayah Gampong Lawet yang sangat strategis, potensi masyarakat yang beragam dan adanya kemauan masyarakat untuk maju, partisipasi masyarkat yang cukup baik. Sedangkan faktor penghambatnya adalah, rendahnya SDM baik itu masyarakat maupun aparat pemerintah gampong, serta dana APBG untuk Gampong Lawet yang tidak sebanding dengan tingkat kebutuhannya.

Kata kunci: Keuchik Gampong, Pembangunan, Gampong Lawet, Aceh Barat

\section{Pendahuluan}

Indonesia memasuki era reformasi yang di tandai dengan bergantinya kekuasaan pemerintahan dari rezim orde baru ke orde reformasi pada tahun 1998. Peralihan kekuasaan dari pada Presiden Soeharto kepada Wakilnya pada saat itu adalah B.J Habibie. Reformasi telah berlangsung selama tujuh belas tahun (1998-2015), selama itu pula telah berganti beberapa kali pucuk pimpinan Negeri ini (Presiden) mulai dari B.J Habibie (1998), KH. Abdurrahman Wahid (1998-2000), Megawati Soekarno Puteri (2000-2004), Susilo Bambang Yudhoyono (2004-2014) dan terakhir Joko Widodo (2014 - Sekarang). Mengawali periode reformasi dengan berbagai masalah yang melanda, mulai dari krisis multi dimensi yang melanda seluruh kawasan Asia Tenggara, memberantas korupsi kolusi dan nepotisme yang ditandai dengan terbentuknya Komisi Pemberantasan Korupsi (KPK), serta melaksanakan agenda Nasional yang sangat penting yaitu pembangunan nasional yang adil dan merata dalam segala bidang di seluruh wilayah Indonesia.

Tuntutan reformasi lainnya yang menarik perhatian adalah tentang desentralisasi pemerintahan dan otonomi daerah. Maka secara langsung mengubah ruang lingkup kewenangan pemerintah di Indonesia, Pemerintah Pusat memberikan kewenangannya kepada pemerintah Daerah untuk mengatur dan mengurus rumah tangga atau daerahnya sendiri.

Tujuan dari otonomi daerah secara umum adalah untuk meningkatkan kualitas keadilan, demokrasi, dan kesejahteraan bagi seluruh unsur bangsa yang beragam di dalam bingkai Negara Kesatuan Republik Indonesia (NKRI). Salah satu caranya adalah meningkatkan daya guna dan hasil guna penyelenggaraan pemerintahan di daerah, terutama dalam pelaksanaan pembangunan dan pelayanan kepada masyarakat serta untuk meningkatkan pembinaan kestabilan politik dan kesatuan bangsa.

Pemerintah Daerah sebagai perangkat Pemerintah Pusat dalam proses pembangunan untuk mewujudkan kesejahteraan masyarakat di daerah harus mampu mengakomodir, mengelola, dan memberdayakan sumber-sumber yang ada secara keseluruhan di daerahnya masing-masing, baik sumber daya alam yang ada maupun sumber daya manusia yang ada di daerah.

Dengan demikian salah satu bagian dalam sistem pembangunan daerah adalah penyelenggaraan pembangunan Gampong (Desa) yang dilaksanakan oleh pemerintah Gampong yang merupakan 
pelaksana pembangunan "garis depan" dalam pemerintahan Indonesia sesuai dengan pelaksanaan Otonomi Daerah yang telah di amanatkan dalam Undang - Undang Republik Indonesia Nomor 32 Tahun 2004 tentang pemerintahan daerah. Dalam Undang - Undang Republik Indonesia Nomor 6 Tahun 2014 tentang Desa. Pembangunan Desa adalah upaya peningkatan kualitas hidup dan kehidupan untuk sebesar-besarnya kesejahteraan masyarakat Desa.

Pembangunan Gampong merupakan satu diantara bagian integral dari pembangunan Nasional, yang di dalamnya terdapat usaha peningkatan kualitas sumber daya manusia dan pengelolaan sumber daya alam yang dilakukan secara berkelanjutan dan terencana berdasarkan pada potensi dan kemampuan Gampong. Dalam pelaksanaannya, pembangunan yaitu mewujudkan kehidupan masyarakat Gampong yang mandiri, maju, sejahtera dan berkeadilan.

Dalam Undang-Undang Republik Indonesia Nomor 6 Tahun 2014 Tentang Desa menyebutkan bahwa Desa adalah kesatuan masyarakat hukum yang memiliki batas wilayah yang berwenang untuk mengatur dan mengurus urusan pemerintahan, kepentingan masyarakat setempat berdasarkan prakarsa masyarakat, hak asal usul, dan/atau hak tradisional yang diakui dan dihormati dalam sistem pemerintahan Negara Kesatuan Republik Indonesia. Dilaksanakan oleh penyelenggaraan urusan pemerintahan oleh pemerintah Desa yang dipimpin oleh seorang kepala Desa sebagai badan eksekutif dan Badan Permusyawaratan Desa sebagai badan legislatifnya. Dengan demikian dalam melaksanakan suatu pembangunan tersebut yang nantinya akan menjadi satu diantara kunci keberhasilan dari pembangunan yang telah direncanakan sebelumnya, sehingga dapat dikatakan satu diantara faktor yang sangat penting dalam menentukan keberhasilan pembangunan Desa adalah peranan dari pemerintah Desa yang dipimpin oleh seorang kepala Desa, karenakan merupakan pemimpin dalam penyelenggaraan pemerintahan Desa.

Kabupaten Aceh Barat adalah salah satu kabupaten di Provinsi Aceh, Indonesia. Sebelum pemekaran, Aceh Barat mempunyai luas wilayah $10.097 .04 \mathrm{~km}^{2}$ atau 1.010.466 Ha dan merupakan bagian wilayah pantai barat dan selatan kepulauan Sumatera yang membentang dari barat ke timur mulai dari kaki gunung Geurutee (perbatasan dengan Aceh Besar) sampai ke sisi Krueng Seumayam (perbatasan Aceh Selatan) dengan panjang garis pantai sejauh $250 \mathrm{~km}$. Sesudah dimekarkan luas wilayah menjadi $2.927,95 \mathrm{~km}^{2}$. Saat ini jumlah penduduk Kabupaten Aceh Barat yaitu 215.418 jiwa (Rencana Kerja Pembangunan Daerah, 2015) seluruhnya bermukim di Gampong dan tersebar di 322 Gampong.

Dalam pelaksanaan pembangunan di gampong, berbagai peran penting dalam penyelenggaraannya termasuk peran dari Kepala (Keuchik) gampong sebagai pemimpin dari gampong yang merupakan ujung tombak pembangunan. Peran seorang Keuchik di gampong sangat besar pengaruhnya, disebabkan karena geuchik merupakan pemegang kekuasaan tertinggi di gampong, yang dapat membuat keputusan, membimbing, membina, mengarahkan, menampung aspirasi masyarakat, serta mempengaruhi anggota masyarakatanya untuk berkerjasama dalam mencapai tujuan dari pembangunan itu sendiri. Oleh karena hal tersebut pelaksanaan pembangunan akan terlaksana dengan baik apabila keuchik melaksanakan tugas dan wewenangnya dengan baik.

Keuchik gampong Lawet yang merupakan satu di antara satuan pemerintahan daerah di Kabupaten Aceh Barat yang memiliki peranan yang besar dalam proses pembangunan di tingkat Gampong. 
Sehingga seorang Keuchik memegang suatu peran yang penting dalam pelaksanaan pembangunan di Gampong. Gampong Lawet merupakan satu diantara gampong yang ada di Kecamatan Pante Ceureumen Kabupaten Aceh Barat yang memiliki jumlah penduduk 382 jiwa pada tahun 2012. Dimana Gampong Lawet dalam hal pembangunan belum terlihat kemajuan yang signifikan dibandingkan dengan gampong-gampong lainnya yang ada di kecamatan Pante Ceureumen. Hal ini dapat dilihat dari belum tersedianya berbagai fasilitas pelayanan publik yang memadai seperti jalan gampong masih serak kerikil, sarana peribadatan (Mesjid) belum ada bangunan baru, pusat kesehatan belum tersedia, sarana pendidikan tidak ada, pusat kreativitas pemuda juga belum tersedia, kantor geuchik belum dibangun, tidak adanya MCK umum, sarana olahraga juga tidak tersedia maksimal.

Selain pembangunan infrastruktur gampong Lawet yang belum begitu maju, berdasarkan observasi awal yang dilakukan peneliti dilapangan ada beberapa kendala dan masalah lain yang terdapat di Gampong Lawet yaitu kurangnya koordinasi Keuchik Gampong dalam meningkatkan dan menggerakkan partisipasi masyarakat untuk ikut serta dalam penyelenggaraan pembangunan di Gampong Lawet seperti jarang ikut serta dalam tahap pembangunan infrastruktur, baik itu pada proses perencanaan, pelaksanaan, pengawasan maupun evaluasi hasil pembangunannya. Sehubungan dengan fenomena tersebut di atas, peneliti terdorong untuk mengadakan suatu penelitian dengan judul "Peran Keuchik Dalam Penyelenggaraan Pembangunan Di Gampong Lawet Kecamatan Pante Ceureumen Kabupaten Aceh Barat.

\section{Kerangka Dasar Teori}

\section{Peran}

Peran adalah suatu perilaku seseorang yang diharapkan dapat membuat suatu perubahan serta harapan yang mengarah pada kemajuan, meskipun tidak selamanya sesuai dengan apa yang diharapkan dan sebagai tolak ukur seseorang sebagai seorang pemimpin apakah orang itu dapat meningkatkan kinerjanya dalam menjalankan tugas - tugas yang diberikan kepadanya sehingga akan membuat orang tersebut dapat memaksimalkan kinerja dalam menjalankan tugas - tugasnya. Peran didefinisikan dari masing - masing pakar diantaranya peran dapat diartikan sebagai perilaku yang diatur dan diharapkan dari seseorang dalam posisi tertentu. Pemimpin didalam sebuah organisasi mempunyai peran, setiap pekerjaan membawa harapan bagaimana penanggung peran beprilaku. Fakta bahwa organisasi mengindentifikasikan pekerjaan yang harus dilakukan dan perilaku peran yang diinginkan yang berjalan seiring pekerjaan tersebut juga mengandung arti bahwa harapan mengenai peran penting dalam mengatur perilaku bawahan menurut Veithzal Rivai (2006:148). Pendapat lain juga mengatakan mendefinisikan peran adalah suatu yang menjadi bagian atau pegangan pimpinan yang terutama dalam terjadinya sesuatu hal atau peristiwa Poerwadarminta (1991:753). Selanjutnya Suhardono (1994:15), menyatakan bahwa peran merupakan seperangkat patokan, yang membatasi apa prilaku yang mesti dilakukan oleh seseorang, yang menduduki posisi suatu jabatan.

Selain itu, menurut Paul B. Horton dan Chester L. Hunt (1999:118), peran juga merupakan prilaku

yang diharapkan dari seseorang yang mempunyai suatu status tertentu. Sedangkan dalam kamus 
sosiologi (1993:440), disebutkan peranan adalah aspek dinamis kedudukan, perangkat hak-hak dan kewajiban-kewajiban, prilaku aktual dari pemegang kedudukan, bagian dari aktivitas yang dimaenkan seseorang. Thoha (2005:263), juga menyebutkan bahwa suatu peranan dirumuskan sebagai suatu rangkaian prilaku yang teratur, yang ditimbulkan karena suatu jabatan tertentu, atau karena adanya suatu kantor yang mudah dikenal. Berdasarkan beberapa konsep diatas dapat disimpulkan bahwa peran merupakan seperangkat kegiatan atau serangkaian perbuatan yang diharapkan dilakukan atau dilaksanakan oleh seseorang atau sekelompok orang atau lembaga karena kedudukannya dalam suatu jabatan.

Adapun menurut suhardono (1994:3) menyatakan bahwa peran merupakan patokan, yang membatasi apa yang mesti dilakukan oleh seseorang yang menduduki suatu jabatan. Adapun peran Kepala Desa (Keuchik Gampong) didalam Gampong:

1. Motivasi, merupakan dorongan, rangsangan, pengaruh, atau stimulus yang diberikan seorang individu kepada individu lainnya sedemikian rupa, sehingga orang yang diberikn motivasi tersebut menuruti atau melaksanakan apa yang dimotivasikan secara kritis, rasional dan penuh tanggung jawab.

2. Fasilitator adalah orang yang memberikan bantuan dalam memperlancar proses komunikasi sekelompok orang, sehingga mereka dapat memahami atau memecahkan masalah bersama-sama.

3. Mobilisator yaitu orang yang mengarahkan atau menggerakkan untuk melakukan sesuatu yang berkaitan dengan sebuah pembangunan guna untuk kepentingan bersama.

Jadi, pemimpin itu ialah seorang yang memiliki satu atau beberapa kelebihan sebagai predisposisi (bakat yang dibawa sejak lahir), dan merupakan kebutuhan dari satu situasi atau zaman, sehingga dia mempunyai kekuasaan dan kewibawaan untuk mengarahkan dan membimbing bawahan. Dia juga mendapatkan pengakuan serta dukungan dari bawahannya, dan mampu menggerakkan bawahan ke arah tujuan tertentu. Jadi peran adalah suatu perilaku seseorang yang diharapkan dapat membuat suatu perubahan serta harapan yang mengarah pada kemajuan, meskipun tidak selamanya sesuai dengan apa yang diharapkan dan sebagai tolak ukur seseorang sebagai seorang pemimpin apakah orang itu dapat meningkatkan kinerjanya dalam menjalankan tugas - tugas yang diberikan kepadanya sehingga akan membuat orang tersebut dapat memaksimalkan kinerja dalam menjalankan tugas - tugasnya.

\section{Pembangunan}

Sebelum ditelaah tentang pembangunan Gampong, maka terlebih dahulu dikemukakan arti serta pengertian dasar dari pembangunan pada umumnya, menurut Tjokroamidjojo (2000:42) pembangunan adalah didalam proses atau usaha - usaha perubahan sosial (sicial chenge) tersebut dapat berarti suatu usaha perubahan dan pembangunan dari keadaan dan kondisi masyarakat yang lebih baik.

Hakikat dari konsep pembangunan adalah suatu usaha yang dilakukan, dalam mengadakan perubahan-perubahan atau perkembangan menuju kearah yang lebih baik dari sebelumnya. 
Pelaksanaan pembangunan tersebut dilaksanakan bersama-sama oleh pemerintah dan masyarakat sesuai dengan pokok pembangunan di mana pembangunan itu harus memberikan kemakmuran dan kesejahteraan bagi masyarakat. Sebelum ditelaah tentang pembangunan Desa, maka terlebih dahulu dikemukakan arti serta pengertian dasar dari pembangunan pada umumnya, menurut Bintoro Tjokroamidjojo (2000:42) mengatakan bahwa pembangunan adalah didalam proses atau usaha-usaha perubahan-perubahan sosial tersebut dapat berarti suatu usaha perubahan dan pembangunan dari keadaan dan kondisi masyarakat yang lebih baik.

Dalam melaksanakan pembangunan perlu adanya suatu usaha dan proses, menurut Khairuddin (2000:24) yang dinyatakan oleh Siagian pembangunan adalah rangkaian usaha yang secara sadar dilakukan. Artinya, keadaan yang lebih baik, yang didambakan oleh suatu masyarakat, serta pertumbuhan yang diharapkan akan terus berlangsung, tidak terjadi dengan sendirinya, apalagi secara kebetulan. Usaha atau proes pembangunan yang dilaksanakan oleh suatu Negara adalah tekad atau keinginan yang disusun berdasarkan pemikiran - pemikiran dan pertimbangan pertimbangan secara luas. Usaha atau proses pembangunan terlihat dengan adanya kehendak untuk menentukan arahan - arahan sebagai pedoman dalam melaksanakan pembangunan tersebut. Demi terwujudnya pembangunan yang berjalan dengan baik dalam suatu Gampong diperlukannya partisipasi dari masyarakat agar pembangunan tersebut dapat berjalan dengan lancar.

Selanjutnya Menurut Efendi (2002:2), pembangunan mempunyai arti yaitu suatu upaya meningkatkan segenap sumber daya yang dilakukan secara terencana dan berkelanjutan dengan prinsip daya guna dan hasilnya merata serta berkeadilan. Kemudian Menurut Kartasasmita (1996:9), mengatakan bahwa pembangunan adalah suatu proses perubahan kearah yang lebih baik melalui upaya yang dilakukan secara terencana.

Proses pembangunan merupakan suatu perubahan sosial budaya, pembangunan menjadi suatu proses yang dapat bergerak maju atas kekuatan sendiri tergantung kepada manusia dan struktur sosialnya. Jadi, pembangunan bukan hanya yang dikonsepsikan sebagai usaha pemerintah belaka. Melainkan pembangunan tergantung dari proses emasipasi diri, dan suatu partisipasi kreatif dalam proses pembangunan.

Dari pendapat-pendapat diatas, jelas bahwa pembangunan merupakan suatu rangkaian pertumbuhan dan perubahan yang berencana yang dilakukan secara sadar oleh suatu masyarakat dimana masyarakat terlibat baik dalam perencanaannya, pelaksanaan, pemanfaatan hasil maupun evaluasi pembangunan. Seiring dengan perkembangan mengenai konsep dan pelaksanaan pembangunan di berbagai Negara, Indonesia juga mengalami perubahan pergeseran paradigma pembangunan, baik dari strategi ekonomi, strategi people centered, hingga pada strategi pemberdayaan masyarakat yang dikatakan suatu alternatif baru dalam pembangunan masyara

\section{Gampong (Desa)}

Gampong sebagai organisasi pemerintah terendah merupakan tumpuan segenap pelaksana urusan pemerintahan dan pembangunan, Dengan berbagai potensi sumber daya yang dimilikinya. Keberadaan dan kehidupan gampong sebagai suatu kesatuan masyarakat dimana bertempat tinggal 
sejumlah penduduk yang berhak mengatur rumah tangganya sendiri adalah suatu organisasi masyarakat yang ada sejak lama mendahului terbentuknya Negara Indonesia. Undang-Undang Republik Indonesia Nomor 6 Tahun 2014 Tentang Desa menjelaskan Desa dan Desa adat atau yang disebut dengan nama lain, selanjutnya disebut Desa, adalah kesatuan masyarakat hukum yang memiliki batas-batas wilayah yang berwenang untuk mengatur dan mengurus urusan pemerintahan, kepentingan masyarakat setempat berdasarkan prakasa masyarakat, hak asal usul, dan /atau hak tradisional yang di akui dan dihormati dalam sistem Pemerintahan Negara Kesatuan Republik Indonesia. Selanjutnya di Desa terdapat Pemerintahan Desa yaitu penyelenggaraan urusan pemerintahan dan kepentingan masyarakat setempat dalam sistem pemerintahan Negara Kesatuan Republik Indonesia.

Kewenangan Desa (Gampong) meliputi:

a) kewenangan berdasarkan hak asal usul;

b) kewenangan lokal berskala Gampong;

c) kewenangan yang ditugaskan oleh Pemerintah, Pemerintah Daerah Provinsi, atau Pemerintah Daerah Kabupaten/Kota; dan

d) kewenangan lain yang ditugaskan oleh Pemerintah, Pemerintah Daerah Provinsi, atau Pemerintah Daerah Kabupaten/Kota sesuai dengan ketentuan peraturan perundangundangan.

Menurut Ndraha (1991:7) bahwa desa yang otonomi adalah desa-desa yang merupakan sumber hukum, artinya desa dapat melakukan tindakan-tindakan hukum. Tindakan-tindakan hukum yang dapat dilakukan antara lain:

1. Mengambil keputusan atau membuat yang dapat mengikat segenap warga desa atau pihak tertentu sepanjang menyangkut penyelenggaraan rumah tangganya.

2. Menjalankan pemerintah desa.

3. Memilih kepala desa.

4. Memiliki harta benda dan kekayaan sendiri.

5. Memiliki tanah sendiri.

6. Menggali dan menetapkan sumber-sumber kekayaan desa.

7. Menyusun anggaran pendapatan dan pengeluaran desa.

8. Menyelenggarakan gotong royog.

9. Menyelenggarakan peradilan desa.

10. Menyelenggarakan urusan lain demi kesejahteraan desa.

Kemudian ada beberapa unsur otonomi desa yang penting menurut Ndraha (1991: 8) yaitu antara lain:

1. Adat tertentu yang mengikat dan ditaati oleh masyarakat desa yang bersangkutan.

2. Tanah pusaka dan kekayaan desa.

3. Sumber-sumber kekayaan desa.

4. Unsur-unsur rumah tangga.

5. Pemerintah desa memegang fungsi mengatur. 
6. Lembaga atau badan perwakilan atau musyawarah yang sepanjang penyelenggaraan urusan rumah tangga desa memegang fungsi menggatur.

Demi terlaksananya program-program pembangunan perdesaan perlu adanya desa-desa yang otonom dibentuk sebagai satu kesatuan masyarakat yang utuh. Setiap suatu masyarakat tersebut perlu diberi tanggung jawab dan peranan tertentu secara langsung dalam soal-soal pembangunan dan pemerintahaan desanya, sehingga masyarakat tidak hanya sebagai objek pembangunan akan tetapi juga sebagai subjek dari pembangunan itu sendiri. Menurut Widjaja (1993:19) bahwa desa merupakan suatu wilayah yang ditempati oleh sejumlah penduduk sebagai kesatuan masyarakat termasuk didalamnya kesatuan masyarakat hukum yang mempunyai organisasi pemerintahan terendah langsung dibawah Camat dan berhak menyelenggarakan rumh tangganya sendiri dalam ikatan Negara Kesatuan Republik Indonesia.

Selanjutnya menurut Dwipayana dkk (2004 : 11) desa "suatu wilayah yang ditempati oleh sejumlah penduduk sebagai kesatuan masyarakat hukum yang mempunyai organisasi pemerintahan terendah langsung dibawah camat" menjadi rumusan yang berbunyi "desa sebagai kesatuan masyarakat hukum yang memiliki kewenangan untuk mengatur dan mengurus kepentingan masyarakat setempat berdasarkan asal-usul desa" sehingga secara sederhana rumusan ini dapat diartikan sebagai keleluasaan desa untuk berkreasi dan menyusun kebijakan desa yang disesuaikan dengan adat-istiadat, kebutuhan, dan aspirasi warganya. Hal ini juga dapat dilihat dari pengertian desa menurut Undang-Undang No 32 Tahun 2004 tentang Otonomi Daerah bahwa yang dimaksud dengan desa adalah desa atau yang disebut dengan nama lain, selanjutnya disebut desa adalah keseluruhan masyarakat hukum yang memiliki batas-batas wilayah yuridis, berwewenang untuk menggatur dan mengurus kepentingan masyarakat setempat, berdasarkan asal-usul dan adatistiadat yang diakui dan dihormati dalam sistem Pemerintahan Negara Republik Indonesia.

Menurut Undang-Undang Republik Indonesia No 11 Tahun 2006 tentang Pemerintahan Aceh (UUPA) menyebutkan gampong atau nama lain adalah kesatuan masyarakat hukum yang berada di bawah mukim dan dipimpin oleh keucik atau nama lain yang berhak menyelenggarakan urusan rumah tangga sendiri.

Mengacu kepada UUPA kedudukan gampong atau nama lain di Aceh berbeda dengan kedudukan Gampong atau nama lain di daerah/provinsi lain di Indonesia. Perbedaan itu terletak pada perangkat pemerintahan yang memiliki kekhususan di Aceh. Aceh mengakui keberadaan mukim sebagai suatu institusi pemerintahan yang kedudukannya berada di bawah kecamatan. Dalam satu mukim berhimpun beberapa buah gampong, ini adalah bentuk perhatian pemerintah Aceh dalam menjaga dan melestarikan kearifan lokal yang ada di Aceh. Pemeritah pusat juga mengakui keberadaan mukim sebagaimana yang tertuang dalam UUPA Bab 15 tentang mukim dan gampong, bagian kesatu pasal 114 ayat (1) dalam wilayah kabupaten/kota dibentuk mukim yang terdiri atas beberapa gampong, selanjutnya dalam ayat (2) mukim dipimpin oleh imuem mukim sebagai penyelenggara tugas dan fungsi mukim yang dibantu tuha peut mukim atau nama lain.

\section{Kepala Desa (Keuchik Gampong)}


Dari sumber Wikipedia Bahasa Indonesia kepala Desa merupakan pimpinan penyelenggaraan pemerintah desa berdasarkan kebijakan yang telah ditetapkan bersama Badan Permusyawaratan Desa (BPD). Dari pendapat tersebut, kepala desa dianggap sebagai bapak atau tokoh masyarakat dalam membuat peraturan desa ataupun dalam mengambil suatu keputusan harus meminta pendapat dari masyarakat melalui rapat desa atau melalui badan permusyawaratan desa. Jadi, kepala desa sebagai kepala pemerintahan bertanggung jawab atas terselenggaranya pemerintahan desa karena kepala desa yang memegang peran sebagai wakil rakyat yang terpilih atau dipilih secara langsung oleh masyarakat desa.

Dalam Peraturan Pemerintah Nomor 72 Tahun 2005 tentang Pemerintahan Desa bab IV paragraf 2 pasal 14 menyatakan bahwa Kepala desa mempunyai peranan sebagai penyelenggara dan penanggung jawab utama di bidang pemerintahan, pembangunan dan kemasyarakatan dalam rangka penyelenggaraan urusan Pemerintah Daerah, urusan pemerintahan yang dimaksud adalah pengaturan kehidupan masyarakat sesuai dengan kewenangan desa seperti pembuatan peraturan desa, pembentukan lembaga kemasyarakatan, pembentukan badan usaha milik desa, dan kerjasama antar desa. Urusan pembangunan yang dimaksud adalah pemberdayaan masyarakat dalam penyediaan sarana dan prasarana fasilitas umum desa, seperti jalan desa, jembatan desa, pasar desa. Urusan kemasyarakatan ialah pembedayaan masyarakat melalui pembinaan kehidupan sosial budaya masyarakat seperti bidang kesehatan, pendidikan, dan adat-istiadat. Untuk menjalankan tugas tertsebut, maka kepala desa mempunyai fungsi yaitu:

a. Menggerakkan potensi masyarakat.

b. Melaksanakan tugas dari pemerintah atasannya.

c. Melaksanakan koordinasi terhadap jalannya Pemerintah desa.

d. Melaksanakan tugas yang telah menjadi tanggung jawabnya baik di bidang pemerintah, pembangunanan dan kemasyarakatan.

\section{Wewenang Kepala Desa (Keuchik Gampong)}

Dalam menjalankan tugasnya, sebagaimana diatur dalam Undang-Undang Nomor 6 tahun 2014 Tentang Desa, yakni dalam fasal 26 ayat (2) wewenang Kepala Desa antara lain:

a. Memimpin penyelenggaraan Pemerintahan Desa;

b. Mengangkat dan memberhentikan perangkat Desa;

c. Memegang kekuasaan pengelolaan Keuangan dan Aset Desa;

d. Menetapkan Peraturan Desa;

e. Menetapkan Anggaran Pendapatan dan Belanja Desa;

f. Membina kehidupan masyarakat Desa;

g. Membina ketenteraman dan ketertiban masyarakat Desa;

h. Membina dan meningkatkan perekonomian Desa serta mengintegrasikannya agar mencapai perekonomian skala produktif untuk sebesar-besarnya kemakmuran masyarakat Desa;

i. Mengembangkan sumber pendapatan Desa; 
j. Mengusulkan dan menerima pelimpahan sebagian kekayaan negara guna meningkatkan kesejahteraan masyarakat Desa;

k. Mengembangkan kehidupan sosial budaya masyarakat Desa;

1. Memanfaatkan teknologi tepat guna;

m. Mengoordinasikan Pembangunan Desa secara partisipatif;

n. Mewakili Desa di dalam dan di luar pengadilan atau menunjuk kuasa hukum untuk mewakilinya sesuai dengan ketentuan peraturan perundang-undangan; dan

o. Melaksanakan wewenang lain yang sesuai dengan ketentuan peraturan perundangundangan.

2. Hak-hak Kepala Desa (Keuchik Gampong);

a. Mengusulkan struktur organisasi dan tata kerja Pemerintah Desa;

b. Mengajukan rancangan dan menetapkan Peraturan Desa;

c. Menerima penghasilan tetap setiap bulan, tunjangan, dan penerimaan lainnya yang sah, serta mendapat jaminan kesehatan;

d. Mendapatkan pelindungan hukum atas kebijakan yang dilaksanakan; dan

e. Memberikan mandat pelaksanaan tugas dan kewajiban lainnya kepada perangkat Desa.

3. Kewajipan Kepala Desa (Keuchik Gampong)

Dalam menjalankan tugasnya, sebagaimana diatur dalam Undang-Undang Nomor 6 tahun 2014 Tentang Desa, yakni dalam fasal 26 ayat (4) Kepala Desa berkewajiban antara lain:

a. memegang teguh dan mengamalkan Pancasila, melaksanakan Undang-Undang Dasar Negara Republik Indonesia Tahun 1945, serta mempertahankan dan memelihara keutuhan Negara Kesatuan Republik Indonesia, dan Bhinneka Tunggal Ika;

b. Meningkatkan kesejahteraan masyarakat Desa;

c. Memelihara ketenteraman dan ketertiban masyarakat Desa;

d. Menaati dan menegakkan peraturan perundang-undangan;

e. Melaksanakan kehidupan demokrasi dan berkeadilan gender;

f. Melaksanakan prinsip tata Pemerintahan Desa yang akuntabel, transparan, profesional, efektif dan efisien, bersih, serta bebas dari kolusi, korupsi, dan nepotisme;

g. Menjalin kerja sama dan koordinasi dengan seluruh pemangku kepentingan di Desa;

h. Menyelenggarakan administrasi Pemerintahan Desa yang baik;

i. Mengelola Keuangan dan Aset Desa;

j. Melaksanakan urusan pemerintahan yang menjadi kewenangan Desa;

k. Menyelesaikan perselisihan masyarakat di Desa;

1. Mengembangkan perekonomian masyarakat Desa;

m. Membina dan melestarikan nilai sosial budaya masyarakat Desa;

n. Memberdayakan masyarakat dan lembaga kemasyarakatan di Desa; 
o. Mengembangkan potensi sumber daya alam dan melestarikan lingkungan hidup; dan

p. Memberikan informasi kepada masyarakat Desa.

4. Pertanggung Jawaban Kepala Desa

Selain kewajiban sebagaimana dimaksud diatas, pada pasal 15 dijelaskan bahwa Kepala Desa mempunyai kewajiban untuk memberikan laporan penyelenggaraan pemerintahan Desa kepada Bupati/Walikota, memberikan laporan keterangan pertanggungjawaban kepada BPD, serta menginformasikan laporan penyelenggaraan pemerintahan Desa kepada masyarakat. Laporan penyelenggaraan pemerintahan Desa ini disampaikan kepada Bupati/Walikota melalui Camat 1 (satu) kali dalam satu tahun. Laporan keterangan pertanggungjawaban kepada BPD sebagaimana diatas disampaikan 1 (satu) kali dalam satu tahun dalam musyawarah BPD. Sedangkan laporan penyelenggaraan pemerintahan Desa kepada masyarakat dapat berupa selebaran yang ditempelkan pada papan pengumuman atau diinformasikan secara lisan dalam berbagai pertemuan masyarakat Desa, radio komunitas atau media lainnya. Laporan Penyelenggaraan Pemerintahan Desa yang dimaksud digunakan oleh Bupati/Walikota sebagai dasar melakukan evaluasi penyelenggaraan pemerintahan Desa dan sebagai bahan pembinaan lebih lanjut.

\section{Metodologi Penelitian}

Penelitian ini merupakan penelitian yang bersifat deskriptif dan apabila dilihat dari tujuannya termasuk penelitian hukum empiris atau non doktrinal. Lokasi penelitian di Pemerintahan Gampong Lawet. Jenis data yang digunakan meliputi data primer dan data sekunder. Teknik pengumpulan data yang dipergunakan yaitu wawancara dan studi kepustakaan baik berupa bukubuku, peraturan perundang-undangan dan sebagainya. Analisis data menggunakan analisis data kualitatif.

Fokus penelitian dari peran Keuchik gampong dalam penyelenggaraan pembangunan di Gampong Lawet Kecamatan Pante Ceureumen Kabupaten Aceh Barat sebagai tugas, wewenang, kewajipan serta fungsi Kepala Desa (Keuchik Gampong) sesuai Undang-Undang Republik Indonesia Nomor 6 Tahun 2014 di antaranya;

1. Peran Keuchik Gampong dalam penyelenggaraan pembangunan, iaitu

a. Mengkoordinasikan pembnagunan Gampong secara partisipatif

b. Membina Perekonomian Gampong

c. Memelihara ketentraman dan ketertiban masyarakat.

d. Mengajukan perencanaan dan menetapkan peraturan gampong bersama Tuha Peut.

2. Faktor pendukung dan penghambat yang dihadapi Keuchik gampong dalam penyelenggaraan pembangunan. 


\section{Hasil Penelitian dan Pembahasan}

\section{Peran Keuchik dalam mengkoordinasikan pembangunan Gampong secara partisipatif}

Dengan lahirnya Undang-Undang Nomor 32 Tahun 2004 tentang otonomi daerah dan UndangUndang Nomor 6 Tahun 2014 tentang Desa memberikan kesempatan kepada masyarakat Gampong untuk mengatur dan mengurus rumah tangganya sendiri, dengan persyaratan yang diamanatkan yakni diselenggarakan dengan memperhatikan prinsip-prinsip demokrasi, peran serta masyarakat, pemerataan, keadilan, serta memperhatikan potensi dan keanekaragaman daerah.

Dalam rangka mencapai tujuan pembangunan gampong secara lebih efektif, maka pemerintah gampong dan masyarakatnya perlu menciptakan suatu strategi pencapaian tujuan tersebut. Dalam merancang strategi yang dimaksud, pemerintah gampong perlu memperhatikan prinsip-prinsip sebagai berikut:

1. Keterpaduan pembangunan gampong, dimana kegiatan yang dilaksanakan memiliki sinergi dengan kegiatan pembangunan yang lain;

2. Partisipatif, dimana masyarakat terlibat secara aktif dalam kegiatan dari proses perencanaan, pelaksanaan, pengawasan dan pemanfaatan;

3. Keberpihakan, dimana orientasi kegiatan baik dalam proses maupun pemanfaatan hasil kepada seluruh masyarakat gampong; dan

4. Otonomi dan desentralisasi, dimana masyarakat memperoleh kepercayaan dan kesempatan luas dalam kegiatan baik dalam proses perencanaan, pelaksanaan, pengawasan maupun pemanfaatan hasilnya.

Masyarakat mempunyai peranan penting dalam keberhasilan pembangunan, termasuk dalam penyelenggaraan pelayanan publik. Peran serta keuchik gampong dalam penyelenggaraan pelayanan publik didefinisikan sebagai suatu partisipasi seluruh anggota masyarakat, baik individu, keluarga atau pun kelompok, untuk bersama-sama mengambil tanggung jawab, mengembangkan kemandirian, menggerakkan, dan melaksanakan upaya penyelenggaraan pelayanan publik.

Banyak hasil dari program-program penyelenggaraan pelayanan publik yang berlandaskan peran-serta masyarakat termasuk program pemerintah gampong kurang berkembang bahkan ada yang sudah tidak berlanjut. Hal ini disebabkan karena para petugas lapangan sebagai motivator dari program tersebut di atas kurang memberikan dorongan/motivasi kepada masyarakat khususnya kepada kepala gampong lebih lanjut secara terus-menerus.

Pemerintah atau swasta yang mempengaruhi keberadaan peran-serta masyarakat tidak satu pun yang dapat berkesinambungan. Demikian pula faktor demografi, seperti usia, agama, pendidikan, jenis kelamin, pekerjaan (tingkat ekonomi) dan sebagainya yang merupakan faktor yang tidak dianggap dapat mempengaruhi peran-serta masyarakat. Satu-satunya faktor dari masyarakat yang masih mungkin dapat melakukan dorongan/motivasi secara berkesinambungan adalah faktor tokoh masyarakat yang dalam hal ini adalah keuchik gampong. 
Dalam pelaksanaan pembangunan gampong mutlak diperlukan keikutsertaan semua komponen yang ada di gampong baik itu pemerintahan gampong itu sendiri, kelembagaan yang ada, swasta serta keikutsertaan masyarakat gampong secara langsung dalam penyusunan rencana pembangunan, pelaksanaan, pengawasan dan pemanfaatannya.

Bentuk koordinasi yang dilakukan secara partisipatif oleh Keuchik gampong adalah melibatkan masyarakat, pihak swasta dan lembaga-lembaga yang ada di gampong dalam proses penyelenggaraan pembangunan. Seperti dalam tahap perencanaan pembangunan gampong yaitu masyarakat yang diwakili oleh Tuha Peut, kepala dusun (kadus) dari masing-masing dusun maupun tokoh-tokoh masyarakat, pihak swasta dalam hal ini pihak kontraktor yang mendapatkan proyek pembangunan di gampong serta lembaga-lembaga gampong lainnya diwajibkan menghadiri musyawarah gampong dan rapat gampong yang dilaksanakan di balai gampong seperti pelaksanaan musyawarah rencana pembangunan (Musrenbang), rapat pembuatan dan penyusunan Anggaran Pendapatan Belanja Gampong (APBG), Rencana Pembangunan Jangka Menengah Gampong (RPJMG), Rencana Kerja Pemerintahan Gampong (RKPG), rapat persiapan pelaksanaan kegiatan-kegiatan yang diadakan di gampong, serta rapat dalam penyelesaian masalah-masalah yang timbul di gampong. Selain diwakili oleh Tuha Peut ataupun ketua kadus, Keuchik gampong juga mempersilahkan kepada masyarakat gampong yang ingin ikut menghadiri rapat-rapat gampong untuk berpartisipasi hadir, hal ini dalam upaya untuk memberikan informasi yang jelas tentang perencanaan pembangunan kepada masyarakat agar mereka tahu persis tujuan pembangunan yang ingin dilaksanakan di gampong serta adanya kesempatan yang diberikan kepada masyarakat untuk mengajukan pertanyaan atau menyampaikan pendapat.

Adapun dalam tahap pelaksanaan pembangunan, Keuchik gampong melibatkan semua pihak termasuk warga masyarakat untuk berpartisipasi membantu melancarkan proses pelaksanaan pembangunan, baik itu membantu dalam bentuk tenaga, material maupun ide. Partisipasi dalam bentuk tenaga dalam hal ini diwujudkan lewat keikutsertaan masyarakat untuk ikut serta dalam kegiatan pembangunan seperti ikut serta membuat jembatan, renovasi rumah adat, perbaikan rumah ibadah dan lain sebagainya. Ini dilaksanakan dengan cara bergotong royong dan pembangunan ini bersifat non proyek. Sedangkan partisipasi dalam bentuk material biasanya memberikan bantuan berupa bahan bangunan atau peralatan kerja, untuk partisipasi dalam wujud bahan material ini adalah dilakukan oleh orang-orang yang notabene-nya yang berkemampuan cukup dalam segi finansial. Seperti perangkat gampong ataupun orang-orang yang dipandang kaya dalam masyarakat setempat. Mereka umumnya dimintai atau suka rela menyumbang material bahan bangunan. Bentuk partisipasi yang terakhir adalah partisipasi masyarakat dalam bentuk ide. Yang dimaksud partisipasi dalam bentuk ide ini adalah sumbangan-sumbangan masyarakat dalam pembangunan yang berupa usul-usul, ide-ide ataupun pemikiran yang disampaikan.

\section{Peran Keuchik dalam memimpin Penyelenggaraan Pemerintahan Gampong}

Berdasarkan penelitian ini diperoleh hasil bahwa peranan Keuchik Gampong dalam penyelenggaraan pemerintahan di gampong Lawet pada prinsipnya merupakan keterlibatan keuchik gampong Lawet dalam melakukan penyelenggaraan pemerintahan berdasarkan tugas dan 
kewajibannya yang diatur dalam peraturan perundang-undangan. Peranan tersebut pada pokoknya menyangkut dua hal yaitu dalam hal urusan tugas pekerjaan di bidang pemerintahan yang terdiri dari empat hal yaitu sebagai Kepala Organisasi Pemerintahan gampong, sebagai pelaksana tugas sehari-hari, sebagai pemimpin masyarakat gampong dan berperan dalam penyusunan peraturan gampong. Dalam hal pembangunan keuchik gampong Lawet mempunyai peranan sebagai penanggung jawab terhadap pembangunan yang bersifat fisik sedangkan dalam hal pembangunan yang bersifat non fisik keuchik gampong Lawet berperan untuk membangun mental warganya yang dilakukan dengan usaha-usaha yang betujuan untuk membuat agar warganya memiliki mental yang baik sehingga mengakibatkan memiliki sikap dan tingkah laku yang baik. Sedangkan dalam hal pelayanan terhadap masyarakat keuchik gampong Lawet bertindak sebagai fasilitator terhadap warganya artinya keuchik gampong Lawet menyediakan fasilitas-fasilitas yang dibutuhkan warganya.

\section{Peran Keuchik dalam Membina Perekonomian Gampong}

Usaha untuk menggalakkan pembangunan gampong yang dimaksudkan untuk memperbaiki dan meningkatkan taraf hidup serta kondisi sosial masyarakat gampong yang merupakan bagian terbesar dari masyarakat gampong yang merupakan bagian terbesar dari masyarakat Indonesia, melibatkan tiga pihak, yaitu pemerintah, swasta dan warga gampong. Dalam prakteknya peran dan prakarsa pemerintah masih dominan dalam perencanaan dan pelaksanaan maupun untuk meningkatkan kesadaran dan kemampuan teknis warga gampong dalam pembangunan gampong. Berbagai teori mengatakan, bahwa kesadaran dan partisipasi warga gampong menjadi kunci keberhasilan pembangunan gampong. Sedangkan untuk menumbuhkan kesadaran warga gampong akan pentingnya usaha - usaha pembangunan sebagai sarana untuk memperbaiki kondisi ekonomi dan dalam meningkatan partisipasi warga gampong dalam pembangunan banyak tergantung pada kemampuan pemimpin gampong khususnya pimpinan atau keuchik gampong. Dari data yang telah diperoleh penulis disini mengenai ekonomi diperoleh sebagai berikut:

\section{Bidang Perkebunan}

Gampong Lawet memiliki lahan yang berpotensi dalam perkebunan, baik dari tanah yang luas serta kondisi alam yang dapat meningkatkan hasil perkebunan, Namun masyarakat juga memiliki lahan yang mereka miliki sendiri yang hasil panennya digunakan untuk keperluan sendiri ataupun di perdagangkan. Pada umumnya komoditas yang ditanam adalah tanaman yang dapat memberi kemudahan baik dari segi perawatannya, pengolahannya serta dari segi pendapatan.

\section{Bidang Pertanian}

Sedangkan untuk bidang pertanian, gampong Lawet memiliki kondisi lahan yang sangat berpotensi dalam bidang pertanian sehingga dapat dikembangkan dan dimanfaatkan dengan baik dan maksimal, pengetahuan yang cukup dan alat yang tersedia sehingga lahan tersebut mampu memberi hasil yang dapat memberi keuntungan bagi masyarakat dalam bidang perdagangan dan hanya digunakan untuk keperluan sendiri seperti tanaman padi, sayur - mayur, dan lain - lain dimana sebagian besar pekerjaan utama masyarakatnya adalah sebagai petani. 
Gampong Lawet memiliki lahan pertanian seluas 150 Ha yang mengelilingi hampir keseluruhan gampong. Selain itu, ada sebagian lahan yang terletak agak berjauhan dengan gampong, kebiasaannya lahan tersebut masyarakat gunakan untuk menanam kacang tanah, jagung dan lain sebagainya. Lahan tersebut terletak di sepanjang Daerah Aliran Sungai (DAS) Krueng Lawet (Sungai Lawet) hingga mencapai $10 \mathrm{Km}$ dari pemukiman penduduk. Namun dalam kurun waktu beberapa tahun terakhir, masyarakat sudah tidak menggunakan lahan-lahan tersebut untuk bercocok tanam, hal ini disebabkan oleh rasa ketakutan petani terhadap ancama satwa liar Teungku Rayeuk (Gajah) yang sering merusak lahan pertanian warga. Konflik satwa yang dilindungi itu dengan petani sudah terjadi sejak puluhan tahun yang lalu, hingga menimbulkan korban jiwa dari penduduk setempat. Setelah jatuhnya korban meninggalnya petani karena diserang oleh gajah, sejak itulah para petani meninggalkan lahan pertaniannya.

Ada sebagian petani yang memiliki keberanian untuk mengalihfungsi lahan pertanian tersebut menjadi lahan perkebunan sawit, namun kebanyakan dari mereka tidak dapat mengambil hasil perkebunannya juga karena ancaman dari Teungku Rayeuk tersebut yang sifatnya merusak tanaman dan mengancam keselamatan jiwa.

\section{Produksi}

Hasil produksi Gampong Lawet seperti gabah, kacang, cabai, sayuran, dan lain - lain, dengan sistem pemasaran sendiri atau sebagai konsumsi pribadi oleh masyarakat tersebut tetapi tidak jarang juga masyarakat mendapat keuntungan yang diharapakan dari hasil penjualan dari hasil pertanian tersebut. Banyaknya jenis tanaman yang diproduksi oleh setiap keluarga yang berada di gampong Lawet sehingga dapat meningkatkan perekonomian penduduk.

\section{Perdangangan}

Gampong Lawet ini dikenal di daerah Pante Ceureumen dengan adanya penjualan hasil pertanian dalam bentuk gabah dan hasil hutan seperti rotan dan lain-lain. Selain itu gampong lawet juga terkenal dengan hasil tambang tradisional berupa emas dan batu giok yang pemasarannya hingga ke provinsi tetangga iaitu Sumatra Utara (Medan). Selain itu, di gampong Lawet juga terdapat beberapa kedai masyarakat yang menjual keperluan masyarakat sehari-hari dan juga ada beberapa warung kopi sebagai tempat berhimpunnya para pemuda gampong.

Peran keuchik dalam membina perekonomian masyarakat sangatlah berpengaruh terhadap kesejahteraan masyarakat gampong. Maka dari itu, untuk mendukung potensi-potensi dan sumber daya yang sudah ada diperlukan sekali proses membangun daya kritis mereka. Selain mengetahui apa yang jadi kelemahan masyarakat dalam membangun perekonomian, mereka juga perlu disadarkan bahwa mereka memiliki kekuatan yang dapat dikembangkan. Kekuatan dalam diri mereka maupun yang berada disekitar mereka, terutama untuk merumuskan, memusyawarahkan, dan menentukan prioritas pembangunan di wilayahnya. Masyarakat masih memerlukan sentuhan tangan pemerintah, untuk meningkatkan dan menggali potensi untuk berpartisipasi dalam membangun lingkungan atau gampongnya.

Bidang perkebunan, pertanian, produksi dan perdagangan merupakan potensi yang sebagian besar dimiliki dan dikuasai oleh masyarakat gampong Lawet. Untuk bidang pertanian mayoritas warga 
yang tergabung dalam kelompok tani bercocok tanam tanaman padi, sedangkan untuk bidang lainnya sudah dijelaskan di atas.

Maka dari itu, masyarakat merasa tersalurkan potensinya karena adanya bantuan oleh gampong melalui keinginan yang besar dari Keuchik gampong yang bekerjasama dengan NGO, salah satunya Yayasan Paramdina Semesta (YPS) Meulaboh yang membantu masyarakat dengan memberikan sarana penunjang berupa peralatan penunjang pertanian seperti mesin handtractor, mesin giling padi, pupuk dan lain-lain. Selain itu, tim PPL pertanian juga di datangkan untuk mengsosialisasikan tata cara bercocok tanam yang baik. Dalam menggerakkan potensi-potensi yang dimiliki oleh masyarakat, Keuchik gampong memiliki peran yang cukup penting dalam mendukung dan membantu masyarakat mendapatkan akses untuk menyalurkan dan mengembangkan keahlian dan kemampuan yang mereka miliki. Dalam realitanya, Keuchik gampong Lawet sudah menjalankan perannya dengan cukup baik, dimana keuchik sudah mendukung masyarakat yang memiliki bermacam-macam keahlian dan potensi seperti di bidang pertanian, peternakan serta potensi di bidang olahraga, kesenian dan budaya untuk dapat dikembangkan agar menjadi sebuah pondasi untuk membangun sumber daya manusia yang berkualitas.

\section{Peran Keuchik Gampong Dalam Memelihara Ketentraman dan Ketertiban Masyarakat}

Dimana dengan adanya rasa aman, maka masyarakat gampong merasa tenang sehingga timbullah masyarakat yang tertib hukum dengan segala peraturan yang berlaku dan begitu pula sebaliknya jika gampong tidak aman maka masyarakat tidak akan taat pada hokum dan aturan-aturan yang berlaku di gampong. Dengan adanya sikap tertib terhadap sesuatu dimana saling menghormati peraturan yang ada, saling mengerti posisi masing-masing, maka masyarakat dapat merasa aman secara jasmani dan psikis, damai dan tenang tanpa adanya gangguan apapun dan itulah yang disebut terciptanya suasana tentram.

Pada dasarnya ketentraman dan ketertiban adalah suatu keadaan yang dinami, aman, teratur dan tenang, yang berjalan secara teratur sesuai aturan hukum dan norma yang berlaku serta tidak datang kerusuhan dan kekacauan sehingga masyarakat di daerah tersebut dapat bekerja dengan tenang dan teratur tanpa perlu rasa was-was dalam melaksanakan aktivitas sehari-hari begitu pun dengan adanya suasana gampong yang aman dan tenteram masyarakat beribadah pun dapat tenang.

Hal ini menunjukkan pula bahwa ketentraman ketertiban masyarakat sangat penting dan menentukan dalam kelancaran jalannya pemerintahan, pelaksanaan pembangunan serta pembinaan kemasyarakatan dalam suatu wilayah/daerah sehingga tercapainya tujuan pembangunan yang diharapkan untuk kesejahteraan masyarakat.

\section{Peran Keuchik Dalam Mengajukan Perencanaan dan Menetapkan Peraturan Gampong Bersama Tuha Peut}


Peraturan gampong merupakan bagian dari peraturan daerah yang dibuat oleh Tuha Peut Gampong bersama Keuchik dimana tata cara pembuatannya diatur oleh Peraturan Daerah Kabupaten/Kota yang bersangkutan. Peraturan gampong sendiri biasanya bersifat lokal dan mengikat warga setempat atau warga gampong lain yang tinggal sementara di gampong tersebut. Peraturan gampong biasanya berhubungan dengan adat istiadat gampong/masyarakat setempat yang telah ada sejak jaman dahulu dan terus dilestarikan oleh para tokoh masyarakat. Terlepas dari itu semua, tidak menutup kemungkinan dimasukkannya beberapa peraturan gampong yang sifatnya menyesuaikan dengan keadaan saat ini untuk menghindari rancunya pelaksanaan dari perturan gampong itu sendiri.

\section{Faktor Pendukung dan Penghambat Penyelenggaran Pembangunan Gampong}

\section{Faktor Pendukung yang dihadapi Keuchik Gampong dalam penyelenggaraan pembangunan}

Ada beberapa faktor pendukung yang sangat mempengaruhi proses penyelenggaraan pembangunan di gampong Lawet, di antaranya gampong Lawet memiliki luas tanah persawahan cukup besar dan letak gampong yang termasuk dalam daerah aliran sungai (DAS) sehingga berpotensi untuk pembangunan di bidang pertanian dan bidang perikanan. Selain itu pula, faktor pendukung lainnya ialah adanya potensi yang beraneka ragam yang dimiliki oleh masyarakat gampong Lawet dan kemauan mereka yang sebenarnya ingin maju tapi tidak tahu harus melakukan apa untuk diri mereka, dalam hal partisipasi tidak terlalu ditemukan kendala, karena pada umumnya mereka selalu turut serta dalam membantu proses penyelenggaraan pembangunan, hal yang seperti ini yang sekarang dimanfaatkan oleh Keuchik gampong untuk bisa membantu mereka dengan memberikan motivasi, menggerakkan potensi yang mereka miliki dengan membuat program-program yang tepat sasaran yang bisa dijadikan wadah untuk mengembangkan kemampuan mereka dan meningkatkan kemandirian mereka dalam membangun diri mereka sendiri dan lingkungannya.

\section{Faktor penghambat yang dihadapi Keuchik gampong dalam penyelenggaraan pembangunan}

Kendala yang dihadapi Keuchik gampong dalam penyelenggaraan pembangunan ialah masih rendahnya Sumber Daya Manusia (SDM) di gampong baik aparatur maupun masyarakatnya, yang dimana sebagian besar masyarakat hanya lulusan SD dan SLTP ataupun SLTA begitu pula aparat desa yang hanya lulusan SLTA bahkan ada yang tidak tamat SLTA. Masih adanya sebagian masyarakat yang memiliki pola pikir tradisional, masih taat dengan adat istiadat dan budaya nenek moyang yang dianut yakni yang masih memegang teguh tradisi tersebut ialah orang-orang tua. Salah satu budaya yang masih dipertahankan sebagian warga masyarakat gampong Lawet tersebut terlalu banyak pantangan dari orang-orang tua. Sehingga hal yang seperti ini kadang mengganggu proses pelaksanaan pembangunan, Keuchik gampong mendapatkan kesulitan dalam mencari lahan untuk lokasi pembangunan, karena banyak masyarakat yang tidak mahu membebaskan tanahnya untuk pembangunan infrastruktur gampong. Masyarakat yang masih memegang erat adat istiadat 
pula identik berwatak keras sehingga untuk berkomunikasi bersama mereka harus melalui jalur yang sesuai dengan keinginan mereka.

Selain itu, faktor penghambat lainnya ialah dana APBG yang diberikan oleh Pemerintah Daerah Kabupaten Aceh Barat untuk gampong Lawet belum sesuai dengan tingkat kebutuhannya. Selanjutnya dari segi faktor geografisnya, dimana letak wilayah gampong Lawet terlalu jauh dengan Ibukota Kabupaten, sehingga dalam mobilisasi hasil pertanian masyarakat dan segala sesuatu yang berkaitan dengan kebutuhan gampong baik itu kebutuhan dalam urusan pemerintahan maupun urusan pembangunan gampong tidak dapat dijangkau dengan cepat dan proses perekonomian gampong pun berjalan tidak lancar.

\section{Kesimpulan}

Keuchik gampong sangat berperan dalam mengkoordinasikan pembangunan gampong, memimpin penyelenggaraan pemerintahan gampong, membina perekonomian gampong, memelihara ketentraman dan ketertiban gampong dan peran membuat perencanaan peraturan gampong. Faktor pendukung dalam melaksanakan tugas sebagai keuchik gampong di antaranya gampong lawet memiliki luas tanah persawahan yang besar dan letak gampong yang termasuk dalam daerah aliran sungai (DAS) sehingga berpotensi untuk pembangunan di bidang pertanian dan bidang perikanan. Faktor pendukung lainnya ialah adanya potensi yang beraneka ragam yang dimiliki oleh masyarakat gampong Lawet.

Selain faktor pendukung dalam proses melaksanakan peran, juga terdapat faktor penghambat. Faktor penghambat dalam melaksanakan tugas sebagai keuchik gampong Lawet antara lain adalah kurangnya kesadaran msayarakat dalam memberi atau menyumbangkan sesuatu untuk gampongnya sendiri baik itu berupa fisik, dana, maupun pikiran. Terkadang setiap keputusan yang diambil tidak dapat sepenuhnya diterima oleh semua masyarakat yang disebabkan adanya pengaruh - pengaruh dari luar yang menginginkan keputusan tersebut diubah. Sehingga hal ini dapat berpengaruh juga dalam penyelenggaraan pembangunan gampong Lawet. Kurangnya sarana dan fasilitas penunjang yang mendukung Keuchik gampong dalam penyelenggaraan pembangunan di gampong Lawet, misalnya kurangnya teknologi komputer di gampong, pendidikan yang masih sangat kurang sehingga masih banyak kekurangan akan SDM yang diperlukan di gampong Lawet. Tidak hanya itu saja masih ada warga yang menyalah gunakan pinjaman yang semestinya diperuntukkan bersama warga lainnya, dan masih rendahnya SDM yang dimiliki oleh Pemerintah gampong Lawet. 


\section{Daftar Pustaka}

Dwipayana, Ari. 2004. "Otonomi Daerah dan Otonomi Desa: Kritik Konsep dan Implementasi" dalam IRE Pres (2004), Promosi Otonomi Desa. IRE Press: Yogyakarta.

Kartasasmita. 1996. Pembangunan Untuk Rakyat: Memadukan Pertumbuhan dan Pemerataan. Cides: Jakarta

Khairuddin. 2000. Pembangunan Masyarakat: Tinjauan Aspek Sosiologis, Ekonomi, Perencanaan. Liberty: Yogyakarta.

Ndraha, Taliziduhu. 1991. Dimensi-Dimensi Pemerintahan Desa. Bumi Aksara: Jakarta.

Paul B. Horton dan Chester L. Hunt. 1999. Sosiologi. Jakarta: Erlangga

Suhardono, Edy. 1994. Teori Peran. Jakarta: PT Gramedia Pustaka Umum.

Thoha, Miftah. 2005. Perilaku Organisasi: Konsep Dasar dan Aplikasinya. Jakarta: Raja Grafindo Persada.

Tjokroamidjojo Bintoro. 2000. Good Government (Paradigma Baru Manjemen Pembangunan). Jakarta: Universitas Indonesia

Veithzal Rivai. 2006. Credit Manajemen Handbook. Jakarta: Raja Grafindo Persada.

W.J.S, Poerwadarminta. 1991. Kamus Umum Bahasa Indonesia. Jakarta: Balai Pustaka.

Widjaja, A.W. 1993, Komunikasi dan Hubungan Masyarakat, Bumi Aksara: Jakarta.

Sumber lain

\section{Dokumen-Dokumen:}

Undang-Undang Republik Indonesia Nomor 6 Tahun 2014 Tentang Desa

Undang-Undang Republik Indonesia Nomor 11 Tahun 2006 Tentang Pemerintahan Aceh

Undang-Undang Republik Indonesia Nomor 32 Tahun 2004 Tentang Pemerintahan Daerah 
Peraturan Pemerintah Nomor 72 Tahun 2005 tentang Pemerintahan Desa 